\title{
Tat-CIAPIN1 protein prevents against cytokine-induced cytotoxicity in pancreatic RINm5F $\beta$-cells
}

\author{
Hyeon Ji Yeo ${ }^{1, \#}$, Min Jea Shin ${ }^{1, \#}$, Dae Won Kim², Hyeok Yil Kwon ${ }^{3}$, Won Sik Eum ${ }^{1, *}$ E Soo Young Choi, ${ }^{1, *}$ \\ ${ }^{1}$ Department of Biomedical Science and Research Institute of Bioscience and Biotechnology, Hallym University, Chuncheon 24252, \\ ${ }^{2}$ Department of Biochemistry and Molecular Biology, Research Institute of Oral Sciences, College of Dentistry, Gangneung-Wonju National \\ University, Gangneung 25457, ${ }^{3}$ Department of Physiology, College of Medicine, Hallym University, Chuncheon 24252, Korea
}

\begin{abstract}
Cytokines activate inflammatory signals and are major mediators in progressive $\beta$-cell damage, which leads to type 1 diabetes mellitus. We recently showed that the cell-permeable Tat-CIAPIN1 fusion protein inhibits neuronal cell death induced by oxidative stress. However, how the Tat-CIAPIN1 protein affects cytokine-induced $\beta$-cell damage has not been investigated yet. Thus, we assessed whether the Tat-CIAPIN1 protein can protect RINm5F $\beta$-cells against cytokine-induced cytotoxicity. In cytokineexposed RINm5F $\beta$-cells, the transduced Tat-CIAPIN1 protein elevated cell survivals and reduced reactive oxygen species (ROS) and DNA fragmentation levels. The Tat-CIAPIN1 protein reduced mitogen-activated protein kinases (MAPKs) and NF-KB activation levels and elevated Bcl-2 protein, whereas Bax and cleaved Caspase- 3 proteins were decreased by this fusion protein. Thus, the protection of RINm5F $\beta$-cells by the Tat-CIAPIN1 protein against cytokine-induced cytotoxicity can suggest that the Tat-CIAPIN1 protein might be used as a therapeutic inhibitor against RINm5F $\beta$-cell damage. [BMB Reports 2021; 54(9): 458-463]
\end{abstract}

\section{INTRODUCTION}

Type 1 diabetes mellitus (T1DM), a chronic autoimmune disease, occurs primarily in childhood and is characterized by hyperglycemia that destroys pancreatic $\beta$-cells. T1DM is increasing and affecting millions of people worldwide. It is well known that environmental and genetic factors affect the development

*Corresponding authors. Soo Young Choi, Tel: +82-33-248-2112; Fax: +82-33-248-3202; E-mail: sychoi@hallym.ac.kr; Won Sik Eum, Tel: +82-33-248-3221; Fax: +82-33-248-3202; E-mail: wseum@hallym. ac.kr

${ }^{\#}$ These authors contributed equally to this work.

https://doi.org/10.5483/BMBRep.2021.54.9.040

Received 23 March 2021, Revised 31 March 2021, Accepted 20 April 2021

Keywords: Cytokines, Diabetes, MAPK, NF-кB, Protein therapy, TatCIAPIN1 of T1DM (1-5). In the early stages of T1DM, the infiltration of inflammatory cells promotes the release of cytokines, such as interleukin- $1 \beta$ (IL-1 $\beta$ ), tumor necrosis factor- $\alpha$ (TNF- $\alpha$ ), and interferon- $\gamma(\mathrm{INF}-\gamma)$, and promotes cytotoxicity in pancreatic $\beta$-cells, which may contribute to the impairment of insulin secretion and lead to $\beta$-cell death (6-8). Thus, inhibition of $\beta$-cell damage may ameliorate T1DM progression.

Cytokine-induced apoptosis inhibitor 1 (CIAPIN1; originally named anamorsin) is an identified apoptosis-associated protein. Several studies have reported that CIAPIN1 is an anti-apoptotic molecule that has no homology with the anti-apoptotic proteins, such as Bcl-2, caspase, the IAP families, or other signaltransduction molecules; CIAPIN1 is known as a regulator of the RAS signaling pathway (9-12). CIAPIN1 is expressed in various tissues, including metabolic tissues, and has a critical role in various cancers, including gastric cancer, hepatocellular carcinoma, and renal cancer $(12,13)$. Several previous studies showed that the CIAPIN1 protein inhibits the proliferation of various cancer cells; so this protein could be a new anticancer agent (13-16). In the brain, overexpression of the CIAPIN1 protein reduced dopaminergic neuronal cell death in rat brains. Other studies have reported that this protein is involved in inflammation, ROS, and intracellular signaling-pathway mediators (17-20).

Protein transduction peptides (PTDs) are generally composed of 4-30 basic amino-acid-rich sequences and are promising tools for the delivery of proteins into cells $(21,22)$. In general, the large molecule of protein prevents them from being delivered to cell membranes and the blood-brain barrier (BBB). However, PTD technology permits intracellular delivery of therapeutic molecules without increasing cytotoxicity $(23,24)$. The Tat PTD is a natural peptide from human immunodeficiency virus type 1 and is commonly used to deliver proteins into cells (25-27). We also have reported that the Tat-CIAPIN1 protein reduced cell deaths in oxidative-stress-induced hippocampal neuronal cells and reduced inflammatory responses in LPS-induced Raw 264.7 cells $(28,29)$. In addition, many reports have shown that transduced PTD fusion proteins inhibit cell deaths in oxidative stress- or cytokine-induced cells (28-35). In this study, we investigated whether the Tat-CIAPIN1 protein can protect RINm5F $\beta$-cells against cytokines-induced cytotoxicity.

ISSN: 1976-670X (electronic edition)

Copyright (c) 2021 by the The Korean Society for Biochemistry and Molecular Biology

(c) This is an open-access article distributed under the terms of the Creative Commons Attribution Non-Commercial License (http://creativecommons.org/licenses/by-nc/4.0) which permits unrestricted non-commercial use, distribution, and reproduction in any medium, provided the original work is properly cited. 


\section{RESULTS AND DISCUSSION}

Transduction of the Tat-CIAPIN1 protein into RINm5F $\beta$-cells Much evidence has demonstrated that a transduced fusion protein has been an effective tool for application of therapeutic proteins (28-35). Although the precise mechanism of transduction of Tat fusion proteins has not been well established, this fusion protein seems to be transduced into cells by either direct translocation or endocytosis $(36,37)$. This protein delivery has been getting the spotlight as an alternative means for gene delivery $(38,39)$. To investigate the transductive efficiency of the Tat-CIAPIN1 protein in RINm5F $\beta$-cells, we prepared the cell-permeable Tat-CIAPIN1 protein as described previously (28).

Fig. 1A shows purified Tat-CIAPIN1 and CIAPIN1 proteins. To assess the ability for Tat-CIAPIN1 protein transduction, we treated RINm5F $\beta$-cells with Tat-CIAPIN1 proteins $(0.5-3 \mu \mathrm{M})$ for $1 \mathrm{~h}$ or with Tat-CIAPIN1 proteins at $3 \mu \mathrm{M}$ for 15-60 min. As shown in Fig. 1B and 1C, the Tat-CIAPIN1 protein was transduced into RINm5F $\beta$-cells in a concentration- and time-dependent manner. In addition, the Tat-CIAPIN1 protein levels remained

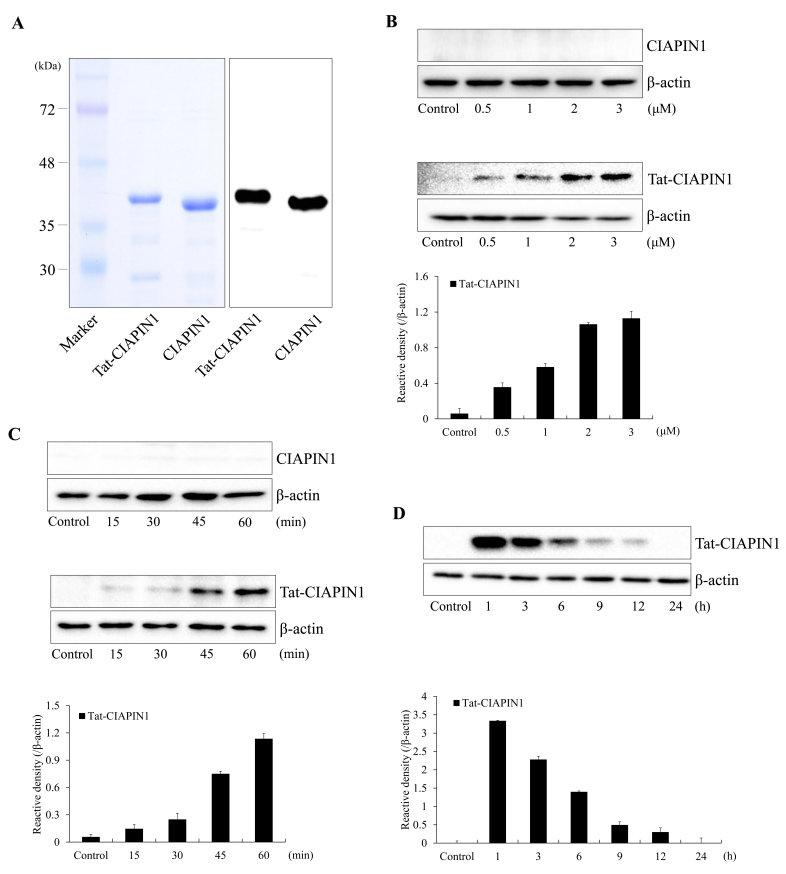

Fig. 1. Purification and transduction of the Tat-CIAPIN1 protein into RINm5F $\beta$-cells. We confirmed purified Tat-CIAPIN1 and CIAPIN1 proteins by $12 \%$ SDS-PAGE and Western blot analysis (A). Transduction of the Tat-CIAPIN1 protein into RINm5F $\beta$-cells. We added the Tat-CIAPIN1 protein $(0.5-3 \mu \mathrm{M})$ to the culture media for $1 \mathrm{~h}$ (B). We then added the Tat-CIAPIN1 protein $(3 \mu \mathrm{M})$ to the culture media for $15-60 \mathrm{~min}(\mathrm{C})$. We assessed the stability of the transduced Tat-CIAPIN1 protein after various time periods. The cells were treated with the Tat-CIAPIN1 protein $(3 \mu \mathrm{M})$, incubated for 1-24 $\mathrm{h}$, and analyzed by Western blot analysis (D). We repeated all experiments at least three times, and present data as mean \pm SEM. stable for $12 \mathrm{~h}$ after transduction and subsequently disappeared over time (Fig. 1D). These results indicate that the Tat-CIAPIN1 protein was transduced into RINm5F $\beta$-cells and was maintained in the cells for at least $12 \mathrm{~h}$. In a previous study, we showed that the Tat-CIAPIN1 protein was transduced into HT-22 and Raw 264.7 cells $(28,29)$.

\section{The Tat-CIAPIN1 protein inhibits cytokine-induced RINm5F $\beta$-cell damage}

It is well known that cytokines promote cytotoxicity in pancreatic $\beta$-cells and lead to $\beta$-cell death (6-8). Therefore, we first investigated whether the Tat-CIAPIN1 protein inhibits cytokineinduced RINm5F $\beta$-cell deaths. As shown in Fig. 2A, transduced Tat-CIAPIN1 protein increased cell survival in a concentrationdependent manner against cytokine-induced cell death. Also, we assessed the toxicity of the Tat-CIAPIN1 protein by measuring the cell viability. As shown in Fig. 2B, the viability of the cells treated with the Tat-CIAPIN1 protein was consistently maintained.

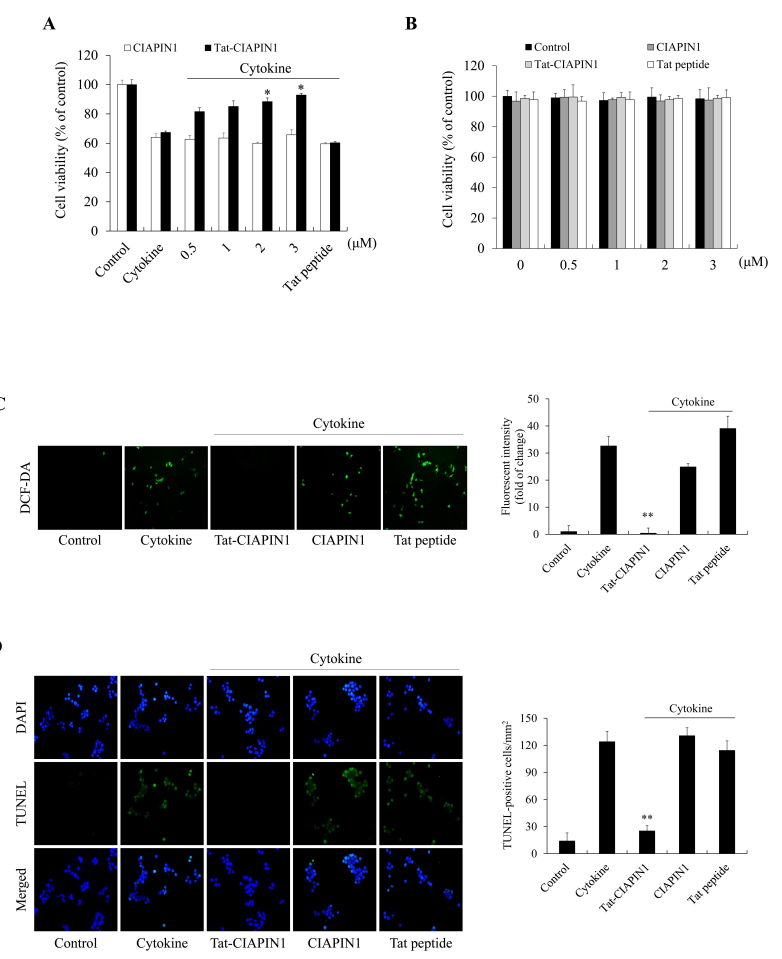

Fig. 2. Effects of the transduced Tat-CIAPIN1 protein on cytokineinduced RINm5F $\beta$-cell damage. We pretreated the Tat-CIAPIN1 protein $(0.5-3 \mu \mathrm{M}$ or $3 \mu \mathrm{M})$ with RINm5F $\beta$-cells for $1 \mathrm{~h}$, and then treated it with cytokines $(5 \mathrm{ng} / \mathrm{ml} \mathrm{IL}-1 \beta, 10 \mathrm{ng} / \mathrm{ml}$ TNF- $\alpha$, and 10 $\mathrm{ng} / \mathrm{ml}$ IFN- $\gamma$ ). Then we assessed cell viability (A and B), ROS production (C), and DNA fragmentation (D) as described in Materials and Methods. ${ }^{* P}<0.01$ and ${ }^{*} * \mathrm{P}<0.001$ compared with cytokine treated cells. We repeated all experiments at least three times, and present data as mean \pm SEM. 
Next, we investigated whether the Tat-CIAPIN1 protein inhibits ROS production and DNA fragmentation (Fig. 2C, D). In cytokine-exposed RINm5F $\beta$-cells, ROS production and DNA fragmentation levels were decreased by the Tat-CIAPIN1 protein. These results indicate that the Tat-CIAPIN1 protein can protect against cytokine-induced cytotoxicity. However, the CIAPIN1 protein or Tat peptide alone did not show the protective effects in cytokine-induced RINm5F $\beta$-cells.

Since pancreatic $\beta$-cells contain significantly fewer antioxidant proteins, including superoxide dismutase, catalase, and glutathione peroxide, than do other tissues in the rat model, several studies have reported that cytokines and oxidative stress are major factors for the destruction of pancreatic $\beta$-cells. The antioxidant proteins play a beneficial role in pancreatic $\beta$-cell viability (40-43).

\section{Effects of Tat-CIAPIN1 against cytokine-induced NF- $k B$, MAPK, and the apoptosis signaling pathway}

Some studies have shown that NF- $\mathrm{KB}$ is a key factor in cytokineinduced pancreatic $\beta$-cell damage and have suggested that inhibition of NF-KB may be a novel strategy for delaying the progression of T1DM $(44,45)$. Sakai et al. (46) have reported that NF- $\mathrm{\kappa B}$ and MAPKs are involved in diabetes complications and diabetic nephropathy. Other studies have shown that MAPK and NF- $\mathrm{KB}$ activation were increased in streptozotocin-induced rat or INS-1 cells (46-48). In this study, we showed that the levels of NF-KB and MAPK activation were markedly increased in cytokine-exposed RINm5F $\beta$-cells by the Tat-CIAPIN1 protein and that this fusion protein reduced NF-KB and MAPK activation levels (Fig. 3).

Since it is known that excessive cytokine leads to cell death via the apoptosis signaling pathway and that $\mathrm{Bcl}-2$ and Bax protein expression is associated with apoptosis (47-50), we examined whether the Tat-CIAPIN1 protein regulates apoptotic signaling (Fig. 4). In cytokine-induced RINm5F $\beta$-cells, the TatCIAPIN1 protein significantly reduced cleaved Caspase-3 and Bax protein expression, whereas $\mathrm{Bcl}-2$ protein expression was significantly increased by this fusion protein. These results indicate that Tat-CIAPIN1 plays a crucial role for cell survival by regulating signaling pathways in cytokine-exposed RINm5F $\beta$-cell (Fig. 4). Zhang et al. (51) showed that overexpression of the CIAPIN1 protein significantly increased $\mathrm{Bcl}-2$ protein expression, whereas Bax protein expression was significantly decreased in hypoxia/reoxygenation-damaged H9c2 cells, suggesting that overexpression of the CIAPIN1 protein reduced apoptosis by the changes of expression of apoptosis-associated proteins in hypoxia/reoxygenation injury (51).

In summary, we showed that the Tat-CIAPIN1 protein inhibited pancreatic $\beta$-cell death by reducing ROS generation, activating NF-KB and MAPK, and regulating the apoptosis-associated proteins in cytokine-induced RINm5F $\beta$-cells. Although the precise function of the CIAPIN1 protein in T1DM remains to be verified, the Tat-CIAPIN1 protein plays a beneficial role in pancreatic $\beta$-cells. Therefore, we suggest that Tat-CIAPIN1
A

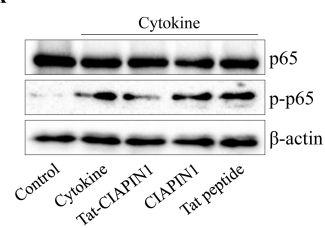

Cytokine
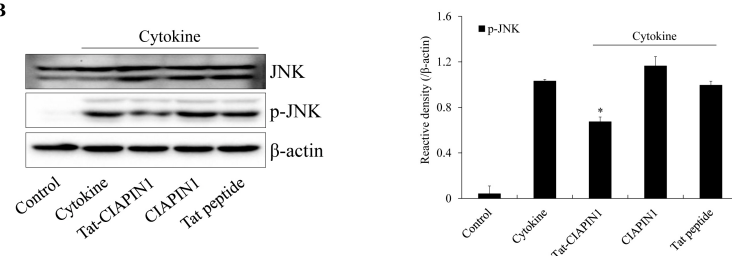

$c$
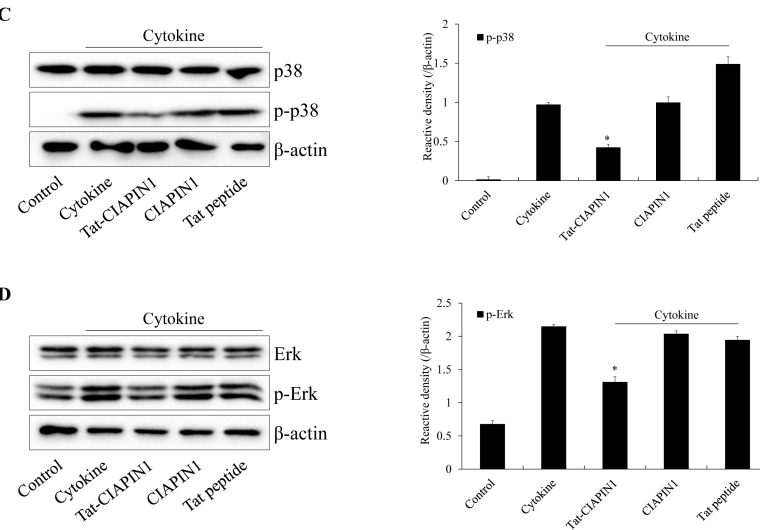

Fig. 3. Effects of the Tat-CIAPIN1 protein on cytokine-induced $N F-\kappa B$ and MAPK activation in RINm5F $\beta$-cells. We pretreated the cells with the Tat-CIAPIN1 protein $(3 \mu \mathrm{M})$ for $1 \mathrm{~h}$ and then treated them with cytokines $(5 \mathrm{ng} / \mathrm{ml} \mathrm{IL-1 \beta ,} 10 \mathrm{ng} / \mathrm{ml}$ TNF- $\alpha$, and $10 \mathrm{ng} / \mathrm{ml}$ IFN- $\gamma$ ). Then, we assessed the levels of NF-KB (A) and MAPK (B-D) by Western blotting and measured the band intensity by densitometer. ${ }^{*} \mathrm{P}<$ 0.01 compared with cytokine-treated cells. We repeated all experiments at least three times, and present data as mean \pm SEM.

may provide a potential therapeutic protein agent for T1DM.

\section{MATERIALS AND METHODS}

\section{Materials}

Tat-CIAPIN1 protein was prepared as described previously study (28). The used antibodies were obtained from Santa Cruz Biotechnology (Santa Cruz, CA, USA) and Cell Signaling Technology (Beverly, MA, USA). 2',7'-Dichlorofluorescein diacetate (DCF-DA) was purchased from Sigma-Aldrich (St. Louis, MO, USA). Cytokines (IL-1, TNF- $\alpha$, and IFN- $\gamma$ ) were obtained from R\&D system (Minneapolis, MN, USA). Fetal bovine serum (FBS) and $1 \%$ antibiotics (penicillin and streptomycin) were purchased from Gibco (Carlsbad, CA, USA). All other agents were of the highest grade available unless otherwise stated. 
A

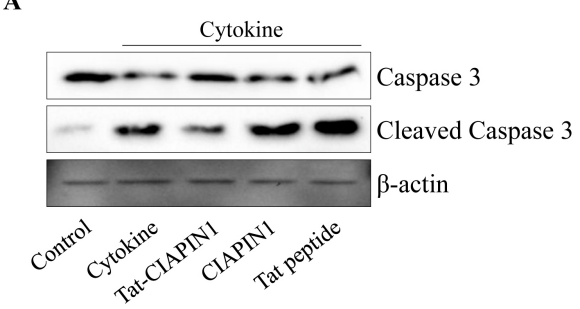

B

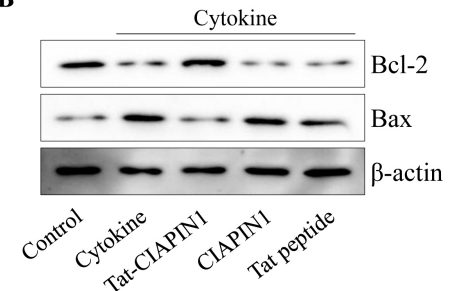

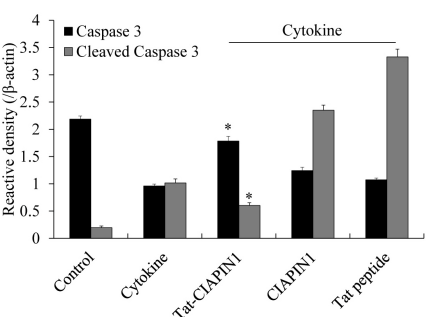

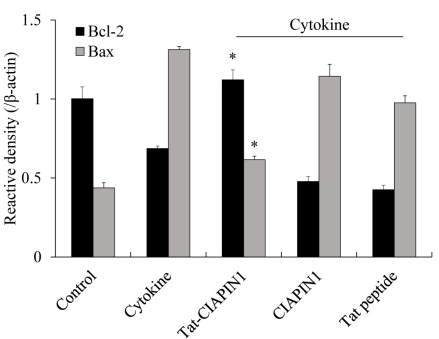

Fig. 4. Effects of the Tat-CIAPIN1 protein on cytokine-induced apoptotic signaling in RINm5F $\beta$-cells. We pretreated the cells with the Tat-CIAPIN1 protein $(3 \mu \mathrm{M})$ for $1 \mathrm{~h}$ and then treated them with cytokines $(5 \mathrm{ng} / \mathrm{ml} \mathrm{IL-1 \beta ,} 10 \mathrm{ng} / \mathrm{ml} \mathrm{TNF}-\alpha$, and $10 \mathrm{ng} / \mathrm{ml}$ IFN- $\gamma$ ). Then, we assessed the indicated protein expression levels (A, B) by Western blotting and measured the band intensity by densitometer. $* \mathrm{P}<0.01$ compared with cytokine-treated cells. We repeated all experiments at least three times, and present data as mean \pm SEM.

\section{Cell culture and Tat-CIAPIN1 protein transduction}

Pancreatic $\beta$-cells (RINm5F $\beta$-cells) were obtained from the ATCC (Manassas, VA, USA) and maintained in RPMl1640 medium containing $10 \% \mathrm{FBS}$ and $1 \%$ antibiotics.

To assess the ability of Tat-CIAPIN1 protein transduction, RINm5F $\beta$-cells were treated with $0.5-3 \mu \mathrm{M}$ or $15-60$ min of Tat-CIAPIN1 protein in culture medium. After washing, transduced levels were determined by Western blotting.

\section{Western blot analysis}

Protein concentrations were determined with Bradford assay (52). Equal amount of proteins were loaded onto $12 \%$ SDSPAGE, and transferred to nitrocellulose membrane. The membranes were incubated in $5 \%$ milk followed by incubation overnight at $4^{\circ} \mathrm{C}$ with primary antibodies. After washing, the membranes were incubated with Horseradish peroxidase-conjugated secondary antibodies at room temperature for $1 \mathrm{~h}$. Then, protein bands were visualized using ECL reagents (Amersham, Franklin Lakes, NJ, USA) $(28,33)$.

\section{Effect of Tat-CIAPIN1 protein on RINm5F $\beta$-cell viability}

Cell viability was analyzed using 3-(4,5-dimethylthiazol-2-yl)2,5-diphenyltetrazolium bromide (MTT) assay. After transduced Tat-CIAPIN1 protein $(0.5-3 \mu \mathrm{M})$ into RINm5F $\beta$-cells for $1 \mathrm{~h}$, cytokines $(5 \mathrm{ng} / \mathrm{ml} \mathrm{IL-1} \beta, 10 \mathrm{ng} / \mathrm{ml} \mathrm{TNF-} \alpha$, and $10 \mathrm{ng} / \mathrm{ml} \mathrm{IFN}-\gamma)$ were exposed the cells for $12 \mathrm{~h}$. Cell viability was determined as described in previous (28).

\section{Measurement of DNA fragmentation levels}

DNA fragmentation was determined using a Cell Death Detection Kit (Roche Applied Science, Basel, Switzerland). After transduced Tat-CIAPIN1 protein ( $3 \mu \mathrm{M})$ into RINm5F $\beta$-cells for $1 \mathrm{~h}$, cytokines $(5 \mathrm{ng} / \mathrm{ml} \mathrm{IL-1 \beta ,} 10 \mathrm{ng} / \mathrm{ml} \mathrm{TNF-} \alpha$, and $10 \mathrm{ng} / \mathrm{ml} \mathrm{IFN- \gamma}$ ) were exposed the cells for $24 \mathrm{~h}$. Then, DNA fragmentation levels were confirmed as described in previous $(28,33)$.

\section{Measurement of ROS level}

Intracellular ROS levels were determined using a DCF-DA staining. After transduced Tat-CIAPIN1 protein $(3 \mu \mathrm{M})$ into RINm5F $\beta$-cells for $1 \mathrm{~h}$, cytokines $(5 \mathrm{ng} / \mathrm{ml} \mathrm{IL-1 \beta ,} 10 \mathrm{ng} / \mathrm{ml} \mathrm{TNF-} \alpha$, and $10 \mathrm{ng} / \mathrm{ml} \mathrm{IFN}-\gamma$ ) were exposed the cells for $22 \mathrm{~h}$ and the cells incubated for $30 \mathrm{~min}$ with DCF-DA $(20 \mu \mathrm{M})$. Then, ROS production levels were confirmed as described in previous $(28,33)$.

\section{Statistical analysis}

Data represent the mean of three experiments \pm SEM. Differences between groups were analyzed by ANOVA followed by a Bonferroni's post-hoc test using GraphPad Prism software (version 5.01; GraphPad Software Inc., San Diego, CA, USA). P $<0.05$ was considered to indicate a statistically significant difference.

\section{ACKNOWLEDGEMENTS}

This research was supported by Basic Science Research Program (2017R1D1A3B04032007 \& 2019R1A6A1A11036849) through the National Research Foundation of Korea (NRF) funded by the Ministry of Education. 


\section{CONFLICTS OF INTEREST}

The authors have no conflicting interests.

\section{REFERENCES}

1. Welters A and Lammert E (2014) Diabetes Mellitus. In: Lammert E, Zeeb M (eds) Metabolism of human diseases: organ physiology and pathophysiology. Springer, Vienna, 163-173

2. Katsarou A, Gudbjornsdottir S, Rawshani A et al (2017) Type 1 diabetes mellitus. Nat Rev Dis Primers 3, 17016.

3. Lukic ML, Pejnovic N and Lukic A (2014) New insight into early events in type 1 diabetes: role for islet stem cell exosomes. Diabetes 63, 835-837

4. Patterson CC, Gyurus E, Rosenbauer J et al (2012) Trends in childhood type 1 diabetes incidence in Europe during 1989-2008: evidence of non-uniformity over time in rates of increase. Diabetologia 55, 2142-2147

5. Patterson CC, Dahlquist GG, Gyurus E, Green A and Soltesz G (2009) EURODIAB Study Group: incidence trends for childhood type 1 diabetes in Europe during 1989-2003 and predicted new cases 2005-20: a multicentre prospective registration study. Lancet 373, 2027-2033

6. Imai Y, Dobrian AD, Weaver JR et al (2013) Interaction between cytokines and inflammatory cells in islet dysfunction, insulin resistance and vascular disease. Diabetes Obes Metab 15, S117-S129

7. Cnop $M$, Welsh $N$, Jonas JC, Jorns $A$, Lenzen $S$ and Eizirik DL (2005) Mechanisms of pancreatic beta cell death in type 1 and type 2 diabetes: many differences, few similarities. Diabetes 54, S97-S107

8. Corbett JA and McDaniel ML (1992) Does nitric oxide mediate autoimmune destruction of beta-cells? Possible therapeutic interventions in IDDM. Diabetes 41, 897-903

9. Shibayama H, Takai E, Matsumura I et al (2004) Identification of a cytokine-induced antiapoptotic molecule anamorsin essential for definitive hematopoiesis. J Exp Med 199, 581-592

10. Hao Z, Li X, Qiao T, du R, Zhang G and Fan D (2006) Subcellular localization of CIAPIN1. J Histochem Cytochem $54,1437-1444$

11. Zhang Y, Fang J and Ma H (2018) Inhibition of miR-182-5p protects cardiomyocytes from hypoxia-induced apoptosis by targeting CIAPIN1. Biochem Cell Biol 96, 646-654

12. Huang Z, Su GF, Hu WJ, Bi XX, Zhang L and Wan G (2017) The study on expression of CIAPIN1 interfering hepatocellular carcinoma cell proliferation and its mechanisms. Eur Rev Med Pharmacol Sci 21, 3054-3060

13. Hao Z, Li X, Qiao T, Du R, Hong L and Fan D (2006) CIAPIN1 confers multidrug resistance by upregulating the expression of MDR-1 and MRP-1 in gastric cancer cells. Cancer Biol Ther 5, 261-266

14. Li X, Wu K and Fan D (2010) CIAPIN1 as a therapeutic target in cancer. Expert Opin Ther Targets 14, 603-610

15. Li X, Fan R, Zou X et al (2008) Reversal of multidrug resistance of gastric cancer cells by down-regulation of CIAPIN1 with CIAPIN1 siRNA. Mol Biol 42, 102-109

16. Wang X, Pan J and Li J (2015) Cytokine-induced apoptosis inhibitor 1 inhibits the growth and proliferation of multiple myeloma. Mol Med Res 12, 2056-2062

17. Park KA, Yun N, Shin DI et al (2011) Nuclear translocation of anamorsin during drug-induced dopaminergic neurodegeneration in culture and in rat brain. J Neural Transm 118, 433-444

18. Sethi G, Shanmugam MK, Ramachandran L, Kumar AP and Tergaonkar V (2012) Multifaceted link between cancer and inflammation. Biosci Rep 32, 1-15

19. Sethi G and Tergaonkar V (2009) Potential pharmacological control of the NF-kappaB pathway. Trends Pharmacol Sci 30, 313-321

20. Lemmon MA and Schlessinger J (2010) Cell signaling by receptor tyrosine kinases. Cell 141, 1117-1134

21. Gump JM and Dowdy SF (2007) TAT transduction: the molecular mechanism and therapeutic prospects. Trends Mol Med 13, 443-448

22. Moon JI, Han MJ, Yu SH et al (2019) Enhanced delivery of protein fused to cell penetrating peptides to mammalian cells. BMB Rep 52, 324-329

23. Frankel AD and Pabo CO (1988) Cellular uptake of the tat protein from human immunodeficiency virus. Cell 55, 1189-1193

24. Kardani K, Milani A, Shabani SH and Bolhassani A (2019) Cell penetrating peptides: the potent multi-cargo intracellular carriers. Expert Opin Drug Deliv 16, 1227-1258

25. Lindsay MA (2002) Peptide-mediated cell delivery: application in protein target validation. Curr Opin Pharmacol 2, 587-594

26. Wadia JS and Dowdy SF (2003) Modulation of cellular function by TAT mediated transduction of full length proteins. Curr Protein Pept Sci 4, 97-104

27. Snyder EL and Dowdy SF (2004) Cell penetrating peptides in drug delivery. Pharm Res 21, 389-393

28. Yeo HJ, Shin MJ, Yeo EJ et al (2019) Tat-CIAPIN1 inhibits hippocampal neuronal cell damage through the MAPK and apoptotic signaling pathways. Free Radic Biol Med $135,68-78$

29. Yeo HJ, Shin MJ, You JH et al (2019) Transduced Tat-CIAPIN1 reduces the inflammatory response on LPSand TPA-induced damages. BMB Rep 52, 695-699

30. van den Berg A and Dowdy SF (2011) Protein transduction domain delivery of therapeutic macromolecules. Curr Opin Biotechnol 22, 888-893

31. Dietz GP (2010) Cell-penetrating peptide technology to deliver chaperones and associated factors in diseases and basic research. Curr Pharm Biotechnol 11, 167-174

32. Kim DW, Shin MJ, Choi YJ et al (2018) Tat-ATOX1 inhibits inflammatory responses via regulation of MAPK and NF-KB pathways. BMB Rep 51, 654-659

33. Shin MJ, Kim DW, Lee YP et al (2013) Tat-glyoxalase protein inhibits against ischemic neuronal cell damage and ameliorates ischemic injury. Free Radic Biol Med 67, 195-210

34. Shin MJ, Kim DW, Jo HS et al (2016) Tat-PRAS40 prevent hippocampal HT-22 cell death and oxidative stress induced animal brain ischemic insults. Free Radic Biol Med 97 250-262

35. Cho SB, Eum WS, Shin MJ et al (2019) Transduced Tat-aldose reductase protects hippocampal neuronal cells 
against oxidative stress-induced damage. Exp Neurobiol 28, 612-627

36. Herbig ME, Weller $K$, Krauss $U$, Beck-Sickinger AG, Merkle HP and Zerbe O (2005) Membrane surfaceassociated helices promote lipid interactions and cellular uptake of human calcitonin-derived cell penetrating peptides. Biophys J 89, 4056-4066

37. Wadia JS, Stan RV and Dowdy SF (2004) Transducible TAT-HA fusogenic peptide enhances escape of TAT-fusion proteins after lipid raft macropinocytosis. Nat Med 10, 310-315

38. El-Sayed A, Futaki S and Harashima H (2009) Delivery of macromolecules using arginine-rich cell-penetrating peptides: ways to overcome endosomal entrapment. AAPS J 11, 13-22

39. Frankel AD, Bredt DS and Pabo CO (1988) Tat protein from human immunodeficiency virus forms a metal-linked dimer. Science 240, 70-73

40. Lei XG and Vatamaniuk MZ (2011) Two tales of antioxidant enzymes on cells and diabetes. Antioxid Redox Signal 14, 489-503

41. Lenzen S, Drinkgern J and Tiedge M (1996) Low antioxidant enzyme gene expression in pancreatic islets compared with various other mouse tissues. Free Radic Biol Med 20, 463-466

42. Lundh M, Scully SS, Mandrup-Poulsen T and Wagner BK (2013) Small-molecule inhibition of inflammatory beta cell death. Diabetes Obes Metab 15, 176-184

43. Rabinovitch A and Suarez-Pinzon WL (1998) Cytokines and their roles in pancreatic islet beta-cell destruction and insulin-dependent diabetes mellitus. Biochem Pharmacol 55, 1139-1149

44. Eldor R, Yeffet A, Baum K et al (2006) Conditional and specific NF-kappaB blockade protects pancreatic beta cells from diabetogenic agents. Proc Natl Acad Sci U S A 103, 5072-5077

45. Grey ST, Longo C, Shukri T et al (2003) Genetic engineering of a suboptimal islet graft with A20 preserves beta cell mass and function. J Immunol 170, 6250-6256

46. Sakai N, Wada T, Furuichi K et al (2002) p38 MAPK phosphorylation and NF-kappa B activation in human crescentic glomerulonephritis. Nephrol Dial Transplant $17,998-1004$

47. Shi $Y$, Wan $X$, Shao N, Ye R, Zhang N and Zhang $Y$ (2016) Protective and anti-angiopathy effects of ginsenoside $\operatorname{Re}$ against diabetes mellitus via the activation of p38MAPK, ERK1/2 and JNK signaling. Mol Med Rep 14, 4849-4856

48. Zhang Y, Mei H, Shan $W$ et al (2016) Lentinan protects pancreatic cells from STZ-induced damage. J Cell Mol Med 20, 1803-1812

49. Riedl SJ and Shi Y (2004) Molecular mechanisms of caspase regulation during apoptosis. Nat Rev Mol Cell Biol 5, 897-907

50. Reed JC (2006) Proapoptotic multidomain Bcl-2/Bax-family protein: mechanisms, physiological roles, and therapeutic opportunities. Cell Death Differ 13, 1378-1386

51. Zhang HJ, Zhang, YN and Teng ZY (2019) Downregulation of miR-16 protects $\mathrm{H} 9 \mathrm{c} 2(2-1)$ cells against hypoxia/ reoxygenation damage by targeting CIAPIN1 and regulation of NF-kB pathway. Mol Med Rep 20, 3113-3122

52. Bradford $M$ (1976) A rapid and sensitive method for the quantitation of microgram quantities utilizing the principle of protein-dye binding. Anal Biochem 72, 248-254 